\title{
Problems in the disinfection of class 1 microbiology safety cabinets
}

\author{
PH EVERALL, CA MORRIS, PR OLIVER, JF BECKER \\ From the Public Health Laboratory and Department of Microbiology, Royal Shrewsbury Hospital, Mytton \\ Oak Road, Shrewsbury
}

SUMMARY Microbiology safety cabinet disinfection procedures using formaldehyde have been tested. Tubercle bacilli were killed by concentrations of formaldehyde obtained by heating commercial formalin irrespective of whether the bacilli were in the cabinet free space or above the prefilters. However, Bacillus stearothermophilus spore papers for the testing of low temperature steam/formaldehyde sterilisers were almost never sterilised and a strain of Staphylococcus epidermidis (NCTC 7944) showed a resistance intermediate between the $B$ stearothermophilus spores and the tubercle bacilli. Tests using a vaccine strain of poliovirus type 3 indicated a considerable degree of resistance of the virus to the action of formaldehyde. No such resistance was demonstrated by vaccinia virus or echovirus 14 .

Chemical and biological evidence is presented which indicates that filter paper discs are an unsuitable carrier material for a challenge organism in testing the efficiency of any formaldehyde sterilising process. Recommendations are made towards developing a satisfactory test procedure.

It is accepted practice to disinfect microbiological safety cabinets with formaldehyde vapour particularly before such operations as filter changing. For some years at Shrewsbury the method described in PHLS Monograph No $6^{1}$ in which $200 \mathrm{ml}$ of an equal volume of commercial formalin and water were boiled away in a sealed cabinet and left undisturbed overnight has been used. The directions imply that the extra water is added to raise the humidity and so enhance the lethal effect of the formaldehyde. Unfortunately one of the effects of the extra water is to cause the inside of the cabinet to become wet from condensation. Because condensation on the load and in the chamber of low temperature steam/formaldehyde sterilisers is known to be a common cause of sterilisation failure, ${ }^{2}$ we tested our cabinet disinfection procedures.

Among the many and varied recommendations for disinfecting safety cabinets (Table 1$)^{13-6}$ only one quotes recent supportive experimental details. ${ }^{6}$ Because of the varied advice and the relative lack of published results we describe the tests we undertook and the results obtained.

Accepted for publication 18 November 1981

\section{Material and methods}

\section{SAFETY CABINETS}

In modern nomenclature these would be "Microbiological Safety Cabinets, class 1 , open fronted, exhaust" but in fact, of the three used for the tests, two are nine years old and one six years old. They are of LEEC manufacture to the recommended PHLS pattern of the time and, as judged by regular air flow measurements with an anemometer, still function well. The cabinet volume is approximately $0.18 \mathrm{~m}^{3}$ plus $0.036 \mathrm{~m}^{3}$ if the enclosure housing the filters is included.

Challenge material was placed in the cabinet free space, above the prefilter, or above the absolute filter. Where the challenge materials were contained in envelopes these were attached to vertical lengths of autoclave tape running from the roof to the base of the cabinet. If not in envelopes they were placed on sterile open Petri dishes either on the base of the cabinet or $215 \mathrm{~mm}$ above it on laboratory tripods.

\section{CHALLENGE MATERIALS}

\section{Bacillus stearothermophilus spore papers}

These were provided by the DHSS and contain approximately $10^{6}$ colony forming units (CFU) per paper. ${ }^{7}$ They can usually, but not always, be steril- 
Table 1 A comparison of recommended methods for the sterilisation of biological safety cabinets

\begin{tabular}{|c|c|c|c|c|}
\hline Source of recommendation & Sterilising agent & Volume of formalin & Exposure time & Fan \\
\hline $\begin{array}{l}\text { DHSS Handbook Safety in } \\
\text { Pathology Laboratories } 1972^{3}\end{array}$ & $\begin{array}{l}\text { Formalin boiled away on } \\
\text { electric heater }\end{array}$ & $100 \mathrm{ml}$ & Not stated & Running \\
\hline $\begin{array}{l}\text { PHLS Monograph No } 61974 \\
\text { The prevention of laboratory- } \\
\text { acquired infection'* }\end{array}$ & $\begin{array}{l}50 \% \text { formalin boiled } \\
\text { away }\end{array}$ & $\begin{array}{l}\text { Formalin } 100 \mathrm{ml} \\
\text { Water } 100 \mathrm{ml}\end{array}$ & Overnight & $\begin{array}{l}\text { On for a "few } \\
\text { minutes only" }\end{array}$ \\
\hline $\begin{array}{l}\text { PHLS Safety Precautions } \\
\text { Notes for Guidance Ist ed } \\
\text { (November, 1976) }{ }^{4 \dagger}\end{array}$ & $\begin{array}{l}\text { Formaldehyde "Laycock's } \\
\text { fumigator" } \\
\text { Formalin "boiling method" }\end{array}$ & $\begin{array}{l}\text { Not present in liquid form } \\
\text { Not stated }\end{array}$ & $\begin{array}{l}\text { Overnight } \\
\text { Not stated }\end{array}$ & $\begin{array}{l}\text { "A few moments" } \\
\text { Not stated }\end{array}$ \\
\hline $\begin{array}{l}\text { Code of practice for the prevention } \\
\text { of infection in clinical } \\
\text { laboratories and post mortem } \\
\text { rooms } 1978^{5} \\
\text { (The Howie report, appendix 9) }\end{array}$ & $\begin{array}{l}\text { Formalin boiled away } \\
\text { or } \\
\text { Formalin with } 10 \mathrm{~g} \mathrm{KMnO}_{4}\end{array}$ & $\begin{array}{l}25 \mathrm{ml} \\
35 \mathrm{ml}\end{array}$ & $\begin{array}{l}\text { Overnight } \\
\text { Overnight }\end{array}$ & $\begin{array}{l}\text { Off overnight } \\
\text { Off overnight }\end{array}$ \\
\hline $\begin{array}{l}\text { Sterilisation of the biological safety } \\
\text { cabinet (Newsome and } \\
\text { Walsingham, 1974) }\end{array}$ & Formalin & $\begin{array}{l}2 \mathrm{ml} \text { per } 0.028 \mathrm{~m}^{3} \bumpeq \\
(25 \mathrm{ml} \text { for a cabinet of } \\
\left.0.38 \mathrm{~m}^{3} \text { capacity }\right)\end{array}$ & 18 hours & Off \\
\hline
\end{tabular}

* Revised 1977 with amendments to formalin and water volumes.

†This document has been superseded by a 2 nd edition, published in 1980 , in which the advice follows the Code of Practice for the Prevention of Infection, $1978^{5}$ and which in addition specifically recommends that a Laycock fumigator should not be used for safety cabinets.

ised in a properly functioning low temperature steam/formaldehyde (LTS/F) steriliser. They were tested in the envelopes in which they were supplied except occasionally when some were exposed, without cover, to the atmosphere in the cabinet.

After exposure to formaldehyde vapour the spore papers were transferred aseptically to $15 \mathrm{ml}$ of tryptone soya broth and incubated at $56^{\circ} \mathrm{C}$ for 14 days.

\section{Staphylococcus epidermidis (NCTC 7944)}

This was obtained from the National Collection of Type Cultures and was chosen because it was one of the organisms employed by a PHLS committee for testing the disinfection of fabrics with gaseous formaldehyde. ${ }^{8} \mathrm{~A}$ suspension in quarter-strength Ringer solution from an overnight culture on nutrient agar was made and adjusted by further dilution to contain $10^{8} \mathrm{CFU} / \mathrm{ml}$. One aliquot of the suspension was further diluted with an equal volume of nutrient broth and a second aliquot with an equal volume of horse serum so as to yield two suspensions: one in $50 \%$ nutrient broth/Ringer solution (nutrient broth suspension) and one $50 \%$ horse serum/Ringer solution (serum suspension). Drops $(0.02 \mathrm{ml})$ of these suspensions were then transferred to sterile filter paper discs and to squares of sterile aluminium foil $\left(1 \mathrm{~cm}^{2}\right)$. The discs and foils were then dried in a desiccator overnight at room temperature with phosphorus pentoxide as the desiccant. Then they were stored at $4^{\circ} \mathrm{C}$ until required. In recovery experiments the yield after "stomaching" for $7 \mathrm{~min}^{7}$ was for filter paper discs $7.0 \times 10^{4}$ (mean of four counts) and for aluminium foils $1.2 \times 10^{5}$ (mean of five counts). In later experiments discs were similarly prepared using fibre glass instead of filter paper as the carrier.
Some of the discs and foils were placed in brown manilla envelopes $\left(50 \mathrm{~mm}^{2}\right)$ which had previously been sterilised in the hot air oven. These were distributed in the cabinet void on autoclave tape as described above. Others, not in envelopes, were exposed in open sterile Petri dishes at cabinet floor level and $215 \mathrm{~mm}$ above floor level on tripods.

After exposure to the formaldehyde, discs and foils were transferred aseptically to $15 \mathrm{ml}$ of tryptone soya broth and incubated at $37^{\circ} \mathrm{C}$ for 7 days. When turbidity developed the broths were subcultured to blood agar plates and the identity of the isolate confirmed by Gram stain and colonial appearance.

\section{Mycobacterium avium (NCTC 8551) and \\ M tuberculosis}

The strain of $M$ avium was chosen because it also had been employed as a test organism in the work of the PHLS committee referred to above. It was grown in Kirschner's medium with the addition of $0.05 \% \mathrm{vol} / \mathrm{vol}$ Tween 80 to ensure dispersed growth. After incubation for six weeks the culture had an optical density of $0.335(1 \mathrm{~cm}$ light path at $650 \mathrm{~nm}$ ) and was used neat in $0.02 \mathrm{ml}$ volumes for the inoculation of discs and foils which were then dried over phosphorus pentoxide.

The strain of $M$ tuberculosis was isolated in this laboratory from a patient with pulmonary tuberculosis. It was processed in the same way as described above for $M$ avium.

All $M$ avium test discs and foils were, after exposure to formaldehyde, incubated in Kirschner's medium for six weeks at the end of which subcultures were made to Löwenstein-Jensen slopes and then incubated for a further six weeks. 
The $M$ tuberculosis test material after exposure to the formaldehyde was cultured in the same way as $M$ avium. Additionally six specimens were sampled into quarter-ounce $(\bumpeq 7 \mathrm{~g})$ screw-capped bottles containing $1 \mathrm{ml}$ quarter-strength Ringer solution and, after homogenising on a rotary mixer for $15 \mathrm{~s}$, inoculated into guinea pigs (two homogenates per animal). These were killed in six weeks and examined in the usual way for inoculation tuberculosis.

\section{Poliovirus 3}

This was isolated from a child's faecal sample. The strain was of presumed vaccine origin, for the child had been given oral polio vaccine some days before.

The strain was passaged to six tubes of baboon kidney cells in maintenance medium. After overnight incubation, when marked cytopathic effects were present, the fluid from these tubes was harvested and pooled. Decimal dilutions of the pooled fluid were prepared and one drop of each dilution was seeded into a fresh tube of baboon kidney cells. Cytopathic effects were seen in dilutions up to and including $10^{-7}$ but not in $10^{-8}$. At the same time one aliquot of the pooled fluid was diluted with an equal volume of newborn calf serum (Flow Laboratories) and a second aliquot with an equal volume of maintenance medium [Eagle's Minimal Essential Medium (MEM) with Earle's Balanced Salt Solution (BSS)] and discs (paper and fibre glass) and foils prepared as described above for Staph epidermidis except that during the desiccation process they were stored at $4^{\circ} \mathrm{C}$ overnight. The inoculation of discs and foils was carried out in this way on three occasions.

After exposure of the discs and foils to the formaldehyde they were transferred to universal containers with $15 \mathrm{ml}$ of maintenance medium and shaken for two minutes. After centrifugation $1 \mathrm{ml}$ of the supernatant was used to inoculate a tube of baboon kidney cells. These were incubated for seven days and passaged to fresh baboon kidney for a further seven days if no cytopathic effect (CPE) was demonstrated. Where CPE did develop this was confirmed as due to poliovirus type 3 by neutralisation tests.

Discs and foils were also sampled after the desiccation process and before exposure to formaldehyde. They were treated in the same way as the materials which had been exposed. Results from these controls indicated the extent to which the drying process alone had inactivated the poliovirus.

\section{Vaccinia virus and echovirus 14}

The source of the vaccinia virus was smallpox vaccine Bl, batch No 3973 (Lister Institute of Preven- tive Medicine). This was cultivated in baboon kidney cells by incubating at $36^{\circ} \mathrm{C}$ for four days by which time CPE was total. One aliquot of the harvested tissue culture fluid was diluted with an equal volume of newborn calf serum and a second aliquot with an equal volume of Eagle's MEM, and these were used to inoculate aluminium foils.

After exposure to formaldehyde the aluminium foils were treated as described for poliovirus above except that the cell lines used were Hep 2 (once) and baboon kidney (once). Unexposed controls were similarly treated.

Echovirus 14 was a stock laboratory virus strain which had been isolated from human faeces. It was processed and used in the same way as was the vaccinia virus.

\section{CARRIER MATERIALS}

Initial testing of the disinfection process was done using the $B$ stearothermophilus spore papers as supplied by the DHSS. When, further challenge organisms were investigated, other carrier agents as well as filter paper were assessed. These were as follows:

\section{Fibre glass discs}

Glass microfibre filters (1 cm diam), Code GF/D kindly supplied by Whatman Laboratories Sales Limited. Before inoculation with the test suspension they were sterilised in glass Petri dishes in a hot air oven at $160^{\circ} \mathrm{C}$ for one hour.

\section{Aluminium foils}

Prepared in the laboratory by cutting squares (1 $\mathrm{cm}^{2}$ ) from a sheet of kitchen aluminium foil. Sterilisation was as described for fibre glass. Drops of suspension were applied to the matt side of the foils to prevent detachment of the dried inoculum.

\section{Filter paper}

These were Whatman AA filter paper discs diameter $13 \mathrm{~mm}$. They were sterilised in the hot air oven.

\section{FUMIGATION WITH FORMALDEHYDE}

The source of the formaldehyde was either liquid formalin (18 occasions) or paraformaldehyde tablets (two occasions). When formalin was being used the desired volume was measured into a beaker placed on a hotplate inside the cabinet. After positioning the challenge material, the aperture of the cabinet was sealed with a sheet of perspex. The hotplate was switched on from outside the cabinet and switched off just before the beaker boiled dry. The cabinet was then left sealed for $18 \mathrm{~h}$ after which the fan was run for $10 \mathrm{~min}$ before opening up and sampling the challenge materials. The volume of formalin used 
was $100 \mathrm{ml}$ on three occasions, $25 \mathrm{ml}$ on 12 occasions and $13 \mathrm{ml}$ on three occasions.

Initially when using paraformaldehyde, four tablets $(1 \mathrm{~g})$ were employed exactly as described by Newsome and Walsingham ${ }^{6}$ but on reweighing the tablets at the end of the experiment it was found that only half of the material had been vaporised. In a second test therefore the heating period was increased from two to four hours and the stream of hot air from a hair drier was directed on to the tablets in an open-ended glass tube (40 $\mathrm{mm}$ diam). At the end of this experiment the total unvaporised residue of paraformaldehyde was less than $200 \mathrm{mg}$.

\section{TEMPERATURE MEASUREMENTS}

Temperatures produced in the cabinet during the boiling away of formalin solution and during the volatilisation of paraformaldehyde were recorded using a Chessel three point recorder and copper/ constantan thermocouples.

\section{ESTIMATION OF FORMALDEHYDE RESIDUES}

Reseeding experiments on tryptone soya broth cultures, which remained clear after 14 days incubation, indicated the likely presence of formaldehyde. Uninoculated filter paper and fibre glass discs were then included in subsequent cabinet fumigation procedures. At the end of the procedure these discs were sampled individually into small plastic tubes and eluted by shaking in $1 \mathrm{ml}$ of distilled water and incubating at $56^{\circ} \mathrm{C}$ for one hour after which the deposits were removed by centrifugation. The formaldehyde liberated from the disc was estimated by the chromotropic acid reaction. ${ }^{9}$

\section{Results}

\section{Bacillus stearothermophilus}

In eight separate experiments a total of 88 spore papers were exposed to formaldehyde. Only one of these gave no growth on subsequent incubation. The formaldehyde was generated from $25 \mathrm{ml}$ formalin (three experiments), $100 \mathrm{ml}$ formalin with $100 \mathrm{ml}$ water (three experiments), and from $2 \mathrm{~g}$ and $4 \mathrm{~g}$ of paraformaldehyde (one experiment each). Of the 88 spore papers 62 were in envelopes and 26 were fully exposed on Petri dishes. Ten of the spore papers in envelopes were positioned above the Hepa filter: the remainder were all in the cabinet void. The single spore paper not showing growth was in an envelope on the floor of the cabinet. The details of the experiments are summarised in Table 2.

\section{Staphylococcus epidermidis}

In the course of seven separate experiments, employing $25 \mathrm{ml}$ formalin (five experiments) and $13 \mathrm{ml}$
Table 2 Exposure of B stearothermophilus spores to formaldehyde

\begin{tabular}{llll}
\hline Source of formaldehyde & $\begin{array}{l}\text { No of } \\
\text { experiments }\end{array}$ & $\begin{array}{l}\text { Spore papers } \\
\text { in envelopes }\end{array}$ & $\begin{array}{l}\text { Spore papers } \\
\text { fully exposed }\end{array}$ \\
\hline $\begin{array}{l}\text { Formalin }(25 \mathrm{ml}) \\
\begin{array}{l}\text { Formalin }(100 \mathrm{ml}) \\
\text { plus water }(100 \mathrm{ml})\end{array}\end{array}$ & 3 & 11 & 10 \\
$\begin{array}{c}\text { Paraformaldehyde }(2 \mathrm{~g}) \\
\text { plus water }(12 \mathrm{ml})-\end{array}$ & 1 & $31^{*}$ & 0 \\
$\begin{array}{c}\text { that is } 4 \mathrm{~g} \text { minus } 2 \mathrm{~g} \text {; } \\
\text { see text }\end{array}$ & 20 & 0 \\
$\begin{array}{c}\text { Paraformaldehyde }(4 \mathrm{~g}) \\
\text { plus water }(25 \mathrm{ml})\end{array}$ & 1 & & \\
Total & 8 & 0 & 16 \\
\hline
\end{tabular}

*The single sample yielding no growth was in this group. tIncludes 10 spore papers placed above the Hepa filter.

of formalin (two experiments), survival occurred in 72 of 198 tests with Staph epidermidis. The results varied with the carrier material, with the suspending fluid, and according to whether or not the test specimen was or was not contained in an envelope. Table 3 sets out the results obtained in more detail. It is apparent that the most resistant test piece was a suspension of Staph epidermidis in 50\% serum broth dried on aluminium foil and contained in an envelope. However, attempts to recover the test organism failed with all but one of 74 test pieces where the carrier was a paper disc. Only a few tests were done using fibre glass discs. The results indicated a recovery rate similar to that with aluminium foil. Some of these variations in recovery were thought to be due to differences in absorptive capacity of the carrier materials for formaldehyde resulting in varying amounts of this chemical being carried over to the culture medium used for incubation. Some simple experiments were therefore performed in which broths containing paper discs from which growth had not been elicited were reseeded with the test organism. Twenty-three broths were tested in this way and in nine of them the probable presence of formaldehyde was indicated as judged by failure to produce growth.

\section{Avian and human tubercle bacilli}

Two experiments, both using $25 \mathrm{ml}$ of formalin, were carried out comprising 20 tests with $M$ avium and 12 tests with $M$ tuberculosis. No mycobacteria were recovered in cultures nor did any of the guinea pigs show evidence of tuberculosis when killed six weeks later. The details of these tests are summarised in Table 4.

\section{Poliovirus}

Tests were carried out on three occasions. In one the poliovirus was exposed on a variety of carrier materials to the vapour from $13 \mathrm{ml}$ of formalin. Surviving poliovirus was found on $7 / 8$ aluminium foils but on 
Table 3 Survival of Staphylococcus epidermidis after exposure to formaldehyde

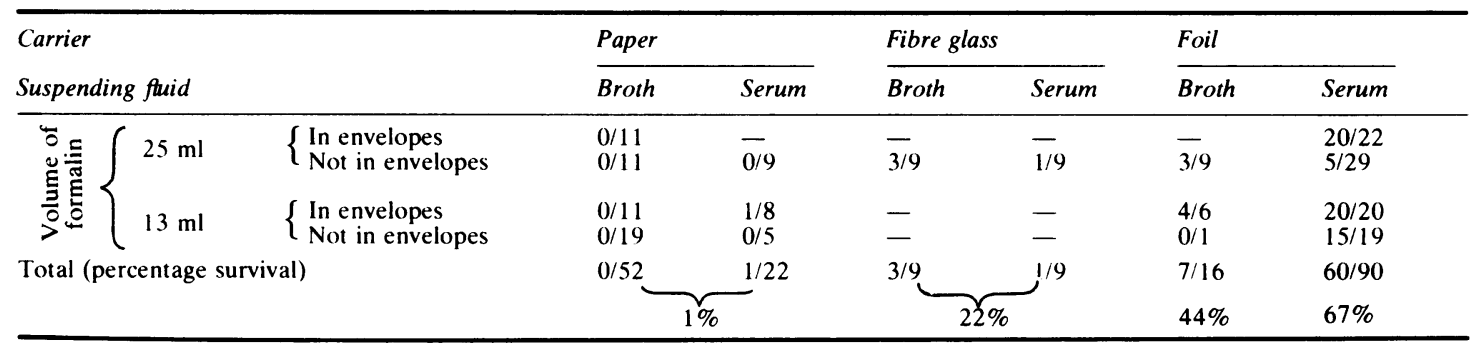

Table 4 Distribution of test materials incorporating avian and human tubercle bacilli

\begin{tabular}{|c|c|c|c|c|}
\hline \multirow[t]{2}{*}{ Test organism } & \multirow[t]{2}{*}{ Site } & \multirow[t]{2}{*}{ Carrier material } & \multicolumn{2}{|c|}{ No and method of testing } \\
\hline & & & Culture & Animal inoculation \\
\hline M tuberculosis & $\begin{array}{l}\text { Above prefilter } \\
\text { In cabinet }\end{array}$ & $\begin{array}{l}\text { Aluminium } \\
\text { Aluminium }\end{array}$ & $\begin{array}{l}2 \\
4\end{array}$ & $\begin{array}{l}2 \\
4\end{array}$ \\
\hline$M$ avium & $\begin{array}{l}\text { Above prefilter } \\
\text { In cabinet }\end{array}$ & $\begin{array}{l}\text { Aluminium } \\
\text { Fibre Glass } \\
\text { Aluminium } \\
\text { Fibre Glass }\end{array}$ & $\begin{array}{l}2 \\
2 \\
8 \\
8\end{array}$ & - \\
\hline Totals & & & 26 & 6 \\
\hline
\end{tabular}

Formalin $(25 \mathrm{ml})$ was used for each test. The 26 test pieces were all culture-negative; the six test pieces inoculated into guinea pigs were also négative.

none of eight fibre glass discs or of eight paper discs. In the other two experiments where foil alone was used and the formalin volume was increased to 25 $\mathrm{ml}$, there were $4 / 24$ and $6 / 24$ survivors respectively. However, the examination of control discs and foils which had not been exposed to formaldehyde after inoculation with poliovirus indicated a poor survival following the drying process. The detailed results are shown in Table 5, from which it can be seen that on aluminium foil and after exposure to formaldehyde there were $17 / 56$ survivors $(30 \%)$ whereas in the absence of formaldehyde exposure there were $8 / 14(57 \%)$ survivors.

\section{Vaccinia virus and echovirus 14}

Three experiments, two with vaccinia virus and one with echovirus, were performed using $25 \mathrm{ml}$ of formalin on each occasion. There were no survivors from 36 tests with vaccinia virus on aluminium foil or from 32 tests with echovirus 14 on aluminium foil. Vaccinia virus was recovered from all of 24 unexposed control test pieces irrespective of whether the virus was suspended in MEM or in 50\% newborn calf serum in MEM. Echovirus was recovered from 6/6 controls in MEM but from $0 / 6$ similar controls where the suspending agent contained calf serum (Table 6). This failure to survive in $50 \%$ newborn calf serum was also noted with the poliovirus employed in our tests: it is believed that it may have resulted from the use of old serum.

TEMPERATURE MEASUREMENTS IN THE CABINET These were measured on two occasions when forma- lin was being used and on one occasion when paraformaldehyde tablets were used. Evaporation of 13 $\mathrm{ml}$ of formalin using the hotplate took $12 \mathrm{~min}$. At the end of this time the maximum temperature recorded in the cabinet was $48^{\circ} \mathrm{C}$. Once the hotplate was switched off the temperature in the cabinet fell rapidly (to a maximum of $30^{\circ} \mathrm{C}$ after $45 \mathrm{~min}$ ). However near the floor of the cabinet and farthest away from the hotplate the temperature rose only $8^{\circ} \mathrm{C}$ from its initial level during the whole of the heating period.

When the hair drier was employed to vaporise the paraformaldehyde tablets temperatures rose from $19-22^{\circ} \mathrm{C}$ at the start to reach a maximum of $67^{\circ} \mathrm{C}$ at the end of the four hours. Again temperatures in the cabinet were far from uniform with differences of $27^{\circ} \mathrm{C}$ being recorded at the end of the heating period. Seventy minutes after the hair drier was switched off temperatures in the cabinet had fallen to $23-25^{\circ} \mathrm{C}$.

FORMALDEHYDE RESIDUES ELUTED FROM DISCS A total of 60 paper and 27 fibre discs were examined. There was a marked difference in the analytical results from these two materials. The mean amount of formaldehyde eluted per disc from the filter paper discs was $613 \mu \mathrm{g}$ and from the fibre glass discs was $0.8 \mu \mathrm{g}$. In one experiment twelve paper discs were exposed to the formaldehyde liberated from $13 \mathrm{ml}$ of formalin (mean amount eluted per disc was $208 \mu \mathrm{g}$ ) and in four experiments paper and fibre glass discs were exposed to the formaldehyde from $25 \mathrm{ml}$ of formalin. The mean amounts 
Table 5 Survival of poliovirus type 3 after exposure to formaldehyde

\begin{tabular}{|c|c|c|c|c|c|c|c|c|c|c|c|c|c|}
\hline \multirow{3}{*}{\multicolumn{2}{|c|}{$\begin{array}{l}\text { Carrier material } \\
\text { Suspending fuid* }\end{array}$}} & \multicolumn{6}{|l|}{ Tests } & \multicolumn{6}{|c|}{ Controls (not exposed to formaldehyde) } \\
\hline & & \multicolumn{2}{|c|}{ Paper } & \multicolumn{2}{|c|}{ Fibre glass } & \multicolumn{2}{|l|}{ Foil } & \multicolumn{2}{|c|}{ Paper } & \multicolumn{2}{|c|}{ Fibre glass } & \multicolumn{2}{|l|}{ Foil } \\
\hline & & $M M$ & Serum & $M M$ & Serum & $M M$ & Serum & $M M$ & Serum & $M M$ & Serum & $M M$ & Serum \\
\hline $\begin{array}{l}\text { Volume of } \\
\text { formalin }\end{array}$ & \multirow[t]{2}{*}{$\begin{array}{l}13 \mathrm{ml} \\
25 \mathrm{ml} \\
25 \mathrm{ml}\end{array}$} & $\frac{0 / 4}{-}$ & $\frac{0 / 4}{-}$ & $\frac{0 / 4}{-}$ & $\frac{0 / 4}{-}$ & $\begin{array}{l}4 / 4 \\
4 / 12 \\
6 / 12\end{array}$ & $\begin{array}{l}3 / 4 \\
0 / 12 \\
0 / 12\end{array}$ & $\frac{0 / 1}{-}$ & $\frac{0 / 1}{-}$ & $\frac{1 / 1}{-}$ & $\frac{1 / 1}{-}$ & $\begin{array}{l}1 / 1 \\
3 / 3 \\
3 / 3\end{array}$ & $\begin{array}{l}0 / 1 \\
0 / 3 \\
1 / 3\end{array}$ \\
\hline Total & & $0 / 4$ & $0 / 4$ & $0 / 4$ & $0 / 4$ & $14 / 28$ & $3 / 28$ & $0 / 1$ & $0 / 1$ & $1 / 1$ & $1 / 1$ & $7 / 7$ & $1 / 7$ \\
\hline
\end{tabular}

${ }^{*} \mathrm{MM}=$ maintenance medium; serum $=50 \%$ calf serum in maintenance medium (see text).

The figures in the columns show the numbers of each material from which poliovirus was isolated over the number of materials tested.

Table 6 Survival of vaccinia virus and echovirus

\begin{tabular}{|c|c|c|c|c|}
\hline \multirow[t]{3}{*}{ Virus } & \multicolumn{4}{|c|}{ Survivors/total tests } \\
\hline & \multicolumn{2}{|c|}{$\begin{array}{l}\text { After exposure to } \\
\text { formaldehyde }\end{array}$} & \multicolumn{2}{|c|}{$\begin{array}{l}\text { Not exposed to } \\
\text { formaldehyde (controls) }\end{array}$} \\
\hline & $M M$ & Serum & $M M$ & Serum \\
\hline $\begin{array}{l}\text { Vaccinia virus } \\
\text { Echovirus }\end{array}$ & $\begin{array}{l}0 / 24 \\
0 / 16\end{array}$ & $\begin{array}{l}0 / 12 \\
0 / 16\end{array}$ & $\begin{array}{l}18 / 18 \\
6 / 6\end{array}$ & $\begin{array}{l}6 / 6 \\
0 / 6\end{array}$ \\
\hline
\end{tabular}

The volume of formalin used was $25 \mathrm{ml}$ and the carrier material was aluminium foil.

$\mathbf{M M}=$ Maintenance medium (see text).

Serum $=50 \%$ calf serum in maintenance media (see text).

of formaldehyde eluted per paper disc in these latter four experiments were $548 \mu \mathrm{g}, 596 \mu \mathrm{g}, 538 \mu \mathrm{g}$ and $1517 \mu \mathrm{g}$. The discs were exposed naked in the cabinet except on one occasion when eight discs were placed in envelopes and eight discs were not. The mean eluate for the enveloped discs was $511 \mu \mathrm{g}$ and for the naked discs $583 \mu \mathrm{g}$. On one occasion 12 discs (six paper and six fibre glass) were sampled before the ten-minute airing period at the end of the fumigation process. Analysis of these 12 discs and of the 12 which had been subjected to the normal routine gave the following results-the figures in each case being the mean of six estimations:

$\begin{array}{lll} & \begin{array}{l}\text { No airing before } \\ \text { sampling }\end{array} & \begin{array}{l}\text { Airing before } \\ \text { sampling }\end{array} \\ \text { Filter paper } & 216 \mu \mathrm{g} & 217 \mu \mathrm{g} \\ & \text { formaldehyde } & \text { formaldehyde } \\ \text { Fibre glass } & 1.0 \mu \mathrm{g} & 0.4 \mu \mathrm{g} \\ & \text { formaldehyde } & \text { formaldehyde }\end{array}$

These results are summarised in Table 7.

\section{Discussion}

The success of formaldehyde fumigation in the inactivation of our strains of $M$ tuberculosis, $M$ avium, vaccinia virus and echovirus should not disguise its disadvantages. If an alternative material were available then formaldehyde would not be used. Many of its faults-for example, poor penetration, reliance for effective action on the control of temperature and humidity and chemical reactivity cannot be overcome in the relatively crude fumigation process. It seems unlikely that any form of commercial formaldehyde generator will, however convenient in operation, increase significantly the efficiency of the disinfection process.

The failure to inactivate the poliovirus test material was not unexpected since this virus when exposed to formaldehyde exhibits marked tailing of its sterilisation curve. Such tailing can occur with other viruses and other viricidal agents. ${ }^{10}$ The $B$ stearothermophilus spore preparation is produced for the testing of low temperature steam and formaldehyde (LTS/F) sterilisers in which the users strive to produce optimum conditions of penetration, temperature and humidity and where, in spite of these efforts, failures still occur. Our single "satisfactory" spore test out of the 88 which were performed was probably aberrant and the result of technical failure. The results with Staph epidermidis were quite unexpected. When a carrier material apart from paper was used survival of this organism was common. The new British Standard for microbiological safety cabinets" states "the cabinet user should assess the

Table 7 Elution of formaldehyde from filter paper and fibre glass discs after fumigation

\begin{tabular}{|c|c|c|c|c|}
\hline \multirow{2}{*}{$\begin{array}{l}\text { Volume of formalin used } \\
\text { or fumigation }\end{array}$} & \multicolumn{2}{|c|}{ Filter paper discs } & \multicolumn{2}{|c|}{ Fibre glass discs } \\
\hline & No examined & Mean of formaldehyde (range) ( $\mu g$ ) & No examined & Mean of formaldehyde (range) $(\mu g)$ \\
\hline $3 \mathrm{ml}$ & $\begin{array}{l}12 \\
16\end{array}$ & $\begin{array}{l}208(124-269) \\
548(183-854)\end{array}$ & 12 & $0.7(0.2-1 \cdot 5)$ \\
\hline $\begin{array}{l}25 \mathrm{ml} \text { (four experiments } \\
\text { in all) }\end{array}$ & * $\left\{\begin{array}{c}8 \\
8 \\
8 \\
8\end{array}\right.$ & $\begin{array}{l}596(514-689) \\
1517(1220-2400) \\
583(310-800) \\
511(440-570)\end{array}$ & $\begin{array}{r}8 \\
7 \\
- \\
-\end{array}$ & $\begin{array}{l}1.4(0.2-2 \cdot 3) \\
0.4(0.0-1 \cdot 5) \\
-\end{array}$ \\
\hline Total & 60 & $613(124-2400)$ & 27 & $0.8(0 \cdot 0-2 \cdot 3)$ \\
\hline
\end{tabular}

A total of 16 discs were analysed of which eight were free in the cabinet void $(\mathrm{N})$ and eight were sealed in small brown envelopes (E). 
conditions needed in his own situation by appropriate biological tests; guess-work can be dangerously ineffective." Our results with $B$ stearothermophilus spores, poliovirus and Staph epidermidis confirm the validity of this statement but like the British Standard do not allow a user to answer the question as to what is an "appropriate biological test." A laboratory concerned with a single micro-organism can and should establish whether or not their fumigation process is effective. However, in a routine diagnostic laboratory handling a range of specimens and micro-organisms it is difficult to select an appropriate "test organism." This is compounded by the difficulty in obtaining reproducible results with formaldehyde. ${ }^{8} 12$

Our results with Staph epidermidis are of interest because of the clear effect of the carrier material. One recovery from 74 paper discs contrasted with 67 recoveries from 106 aluminium foils. A similar effect is seen to a lesser extent with poliovirus results. At one time aluminium foil was used almost exclusively for such tests. It has the disadvantage that adhesion of the test material is poor whereas paper and fibre glass have the advantages that they absorb the inoculum and are also easier to handle. However, our results show that paper is an unsatisfactory carrier material for testing the sterilising properties of formaldehyde: the explanation for this is provided by the chemical analyses. If the large number of discs now used in the testing of LTS/F sterilisers demands the use of a porous material then fibre glass discs would appear to offer a more satisfactory alternative.

The amount of formaldehyde eluted from the discs appeared, when taken in conjunction with the crudity of the fumigation process and with the known heterogeneity of atmospheres inside formaldehyde sterilisers, ${ }^{13}$ to be reasonably reproducible within runs (Table 7). In one experiment the amount of formaldehyde eluted was more than twice that on previous and subsequent occasions. The one distinguishing feature of this experiment which could be identified was that it had followed within 24 hours of a previous fumigation. One feature of the absorption by filter paper of formaldehyde was the way in which it was held firmly bound during the airing process but was then easily released by elution with water at $56^{\circ} \mathrm{C}$. It was also of interest that there appeared to be little difference between the formaldehyde taken up by paper discs in envelopes as compared with paper discs naked in the cabinet. However, there is evidence from the Staph epidermidis experiments of a protective effect of an envelope when the carrier material is aluminium foil; such an effect cannot be demonstrated with paper discs since growth on subsequent incubation is rare even from envelopes.
As will have been seen, most of the investigations reported in this paper have been carried out using the fumigation technique (method $A$ ) recommended in Appendix 9 of the Code of practice for the prevention of infection in clinical laboratories and postmortem rooms; ${ }^{5}$ appendix 10 of the same Code recommends $50-100 \mathrm{ml}$ of unheated formalin for disinfecting cryostats. Newsome and Walsingham ${ }^{6}$ were unable to kill $M$ phlei in a safety cabinet using a substantially similar process to that described in appendix 10, and there would appear to be a case for a critical evaluation of that procedure.

\section{Recommendations}

(i) Staff responsible for operations such as filter changing in safety cabinets should be reminded that fumigation with formaldehyde is not completely effective.

Organic material protects micro-organisms from formaldehyde and the importance of proper cleaning before fumigation should be emphasised.

(ii) Work should be carried out to select a nonpathogenic bacterium which would be suitable as a test organism for the fumigation process; test materials using that organism should be made available from a central source.

(iii) Filter paper should not be used as a carrier material for the test organism.

\section{References}

' PHLS Monograph No 6. The prevention of laboratory acquired infection. Public Health Laboratory Service Monograph Series. London: HMSO, 1974.

${ }^{2}$ Cripps N, Deverill CEA, Ayliffe GAJ. Problems with low temperature steam and formaldehyde sterilisers. Hospital Engineering International Federation Issue No 19, 1976;30:9-11.

${ }^{3}$ DHSS handbook. Safety in pathology laboratories. London: DHSS, 1972.

4 PHLS Safety Precautions. Notes for Guidance. 1st ed. Public Health Laboratory Service 1976.

${ }^{5}$ Code of practice for the prevention of infection in clinical laboratories and post-mortem rooms. London: HMSO, 1978.

- Newsome SWB, Walsingham BM. Sterilisation of the biological safety cabinet. J Clin Pathol 1974;27:921-4.

${ }^{7}$ Everall PH, Morris CA. Quantitative recovery of spores from thermophilic spore papers. J Clin Pathol 1978;31:423-5.

- PHLS Committee Report on formaldehyde disinfection. Disinfection of fabrics with gaseous formaldehyde. J Hyg (Camb) 1958;56:488-515.

- Tomsett SL, Smith DC. The reaction between periodic acid and polyhydroxy compounds. Analyst 1953;78:209-16.

${ }^{10} \mathrm{Hiatt} \mathrm{CW}$. Kinetics of the inactivation of viruses. Bacteriological Reviews 1964;28,2:150-63.

" BS 5726. Specification for microbiological safety cabinets. London: British Standards Institution, 1979.

12 Sprague EK. Formaldehyde disinfection in a vacuum chamber. Public Health Reports XIV, September 22 1899. In: Perkins JJ. Principles and methods of sterilisation in Health Service 2nd ed. Springfield, Illinois: Charles Thomas, 1970. 
${ }^{13}$ Marcos D, Wiseman D. Measurement of formaldehyde concentrations in a subatmospheric steam-formaldehyde autoclave. $J$ Clin Pathol 1979;32:567-75.
Requests for reprints to: Dr CA Morris, Public Health Laboratory and Department of Microbiology, The Royal Shrewsbury Hospital, Mytton Oak Road, Shrewsbury SY3 8XH, England. 